\title{
Advertising, Market Share, And Profitability In The Greek Consumer Industry
}

Zoe Ventoura-Neokosmidi, (Email: ventura@aueb.gr), Athens University of Economics \& Business

\begin{abstract}
An empirical investigation of the relationship between advertising to sales ratio, market share and firm profitability was carried out. Cross section analysis was used over 36 companies that produce fast moving consumer goods, for the year 2002. This paper finds that market share has a positive impact on firm profitability. In contrast to our expectation, the influence of market share is greater than that of advertising to sales ratio. To further examine the contribution of each explanatory variable after the other has been included in the model, the partial F-test was used. The obtained results verify the cross section analysis results.
\end{abstract}

\section{INTRODUCTION}

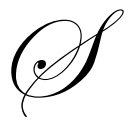

ince competition among firms is growing, their main goal is to define their strategies in order to achieve maximum performance, resulting in greater profit. Hence, it seems that manufacturing industries are focused on the impact of advertising and market share on the profitability.

In the past, many studies have been performed, trying to determine the major factor of influence on profitability. Early work on the advertising - profitability relationship tended to regard advertising as a barrier to entry, see Kaldor (1950), operating through its impact on product differentiation. In Comanor and Wilson (1974), Williamson (1963) and more recently in Kessides (1986) and Pitelis (1991) advertisement has been studied through its role as investment in excess capacity.

The relationship between market share and profitability is perhaps the most-studied single phenomenon in business policy. Although, it has been some decades since the first published studies report a positive market share profitability association (Gale, 1972, Shepherd 1972), the nature of this relationship continues to receive a great deal of attention (Buzzell and Gale, 1987, Jacobson 1988a, Cool et al., 1989, Boulding and Staelin, 1990, Venkatraman and Prescott, 1990 Schwalbach 1991, Szymannski et al., 1993, Fraering and Minor, 1994). While we observe that many practitioners hold the view that higher market share leads to higher profits, research findings indicate that the market share-profitability association is dependent upon strategic and competitive settings, and spurious effects account for at least a sizable component of the measured association.

From all these, the following question arises: is the pursuit of market share an appropriate strategy for the increase of firms' profit? Business strategists are divided on this issue. Some studies indicate that low share businesses can be quite profitable (Woo, 1982, Schwalbach 1991). Moreover, a spurious correlation between market share and industry profitability has been found by Jacobson (1988a), Rumelt and Wensley (1981) and Jacobson and Aaker (1985).

On the other hand, the dominant finding of prior research is a significant positive relationship between market share and profitability. O'Regan Nicholas (2002) has shown that firms with increased market share are likely to have higher performance and in particular achieve enhanced financial performance, greater customer satisfaction and retention. This applies to all firm sizes. To ensure competitive advantage, firms need to consider market share in conjunction with overall profits. 
Scholars support two schools of thought about the effects of advertisement as a competitive factor. In the first school of thought (industrial economics) advertisement is considered as a factor of product differentiation particularly when the latter is plasmatic. It has been proved that advertisement increases profit and reduces consumer welfare by creating product differentiation (Caves and Williamson, 1985) and barriers to entry (important sunk cost). That type of differentiation appears only in markets of imperfect competition.

Another school is focused on the informative character of advertisement, claiming that advertisement makes markets more competitive and reduces profits by supplying consumers with information about price and quality (Greuner, Kamerschen and Klein, 2000).

In the present study, cross section analysis was used to examine the relationship between the gross profit, the market share, as an appropriate strategy, and the plasmatic differentiation (measured by advertisement expenses) of 36 companies, which produce fast moving consumer goods, for the year 2002. In contrast to the above studies which analyze separately the impact of advertisement and market share on the profitability, this work studies the relationship using a single equation. In addition, previous studies disaggregated industry profitability using industry data and not firm level data.

This paper is organized as follows. In section II the model used for our research is demonstrated. Some characteristic parameters of the input data were shown in section III. The derived empirical results were discussed in section IV. Finally some concluding remarks were presented in section V.

\section{THEORETICAL BACKGROUND AND MODEL}

Companies can increase their profits by raising barriers of entry. Advertising is a source of product differentiation, and therefore, a source of competitive advantage in oligopoly industries (Beath, Katsoulacos and Ulph, 1987, 1992, Beath and Ulph, 1990, Swales 1985, Schmalensee 1976, Reedie and Bhoyrub 1981). Successful advertising contributes to a company's sales in two ways, by expanding the demand for the product and by reducing the size of product elasticity.

Product differentiation can be measured by several proxies such as the percentage of the patent and trademark expenditures in total productions and by the advertising intensity (Mata, 1993, Gisser 1991, Milgrons and Roberts, 1986). The way in which advertisement affect demand depends on how consumers learn about product's characteristic (Nelson, 1974). The factors mentioned above reinforce the market share of the companies leading to an increase of their profits.

According to the literature (Schmallensee 1987) and the Lerner index of market power for a firm i, the degree of monopoly power in terms of the effectiveness can be measured by:

$(\mathrm{P}-\mathrm{MC}) / \mathrm{P}=1 / \mathrm{e}$

where $\mathrm{P}$ is the price, MC is firm's marginal cost and e is the price elasticity of the demand. Taking into account the constant return to scale (Martin 1993), the marginal cost equals to average cost which is the normal rate of return of investment. Hence, the marginal cost can be written as:

$\mathrm{MC}=\mathrm{AC}=\mathrm{wL}+\lambda \mathrm{P}^{\mathrm{k}} \mathrm{K} / \mathrm{Q}$

where, AC is the average cost, wL is the wage bill and $\lambda \mathrm{P}^{\mathrm{k}} \mathrm{K}$ is the rental cost of capital $(\lambda$ is the rental cost per euro's worth of capital assets which includes a normal rate of return of investment).

By substituting equation (2) into (1) and rearranging the terms, the following equation is derived

$(\mathrm{PQ}-\mathrm{wL}) / \mathrm{PQ}=1 / \mathrm{e}+\lambda\left(\mathrm{P}^{\mathrm{k}} \mathrm{K}\right) / \mathrm{PQ}=1 / \mathrm{e}+\mathrm{p}^{\mathrm{k}} \mathrm{K} / \mathrm{PQ}$ 
The left side of equation (3) is the rate of return of sales / the cost of capital, while the second term on the right hand side is the capital sales ratio. Due to the lack of data of elasticity the level of advertising intensity can be used since it is related to market structure (Mueller and Rogers, 1980 Sherman, Tollison). According to Martin (1994) market structure can be described by the following equation:

$\log \mathrm{pg}_{\mathrm{i}}=\mathrm{a}_{0}+\mathrm{a}_{1} \log \mathrm{ad}_{\mathrm{i}} / \mathrm{s}+\mathrm{a}_{2} \log \mathrm{m}_{\mathrm{i}}+\mathrm{u}_{\mathrm{it}}$

where $\mathrm{pg}_{\mathrm{i}}$ is the gross profit of the $\mathrm{i}^{\text {th }}$ firm

$\mathrm{ad}_{\mathrm{i}} / \mathrm{s}$ is the expenditure on advertisement to sales ratio of the $\mathrm{i}^{\text {th }}$ firm

$\mathrm{m}_{\mathrm{i}}$ is the market share of the $\mathrm{i}^{\text {th }}$ firm

The sign of the coefficient $a_{1}$ is not expected positive a priori. When advertisement has only an informative character the sign is expected to be negative $\left(a_{1}<0\right)$. On the other hand, it is well known that, when the role of advertisement is to pursue consumers resulting to a change of firms' demand curve (Greuner et al, 2000) and to barriers to entry (Porter 1996a), it increases brand loyalty and profits and hence $\mathrm{a}_{1}>0$ to the present study is expected to be positive. The sign of $a_{2}$ is expected also to be positive since: a) market share leads to a strategic advantage, which creates barriers to entry and b) profit is higher for large firms (Shepherd 1990).

\section{DATA AND VARIABLE DEFINITION}

Firm level data was used to analyze the relationship between the price-cost margin, advertising to sales ratio and market share mainly in food industries. Food industries have been chosen among other industries for two main reasons: a) They are dynamic and advertised sectors in Greek economy and b) there are many relative international enterprises. The input data were selected from various sources. Gross profit, that represents the price-cost margin, was obtained from ICAP, a company that contains all the firms' published balance sheets and income statements on an annual basis. In Greece, firms are obliged to publish their annual data. ICAP also provided market share's data. Market share was calculated by the ratio of firm sales over industry sales. The market-share was used as an appropriate strategy leading to a competitive advantage. Finally, advertising data which are still unpublished came from an advertising company. We represent advertisement by the advertising-sales ratio, which appears in the Comanor -Wilson study to have greater explanatory power than advertisement expenditure per firm.

The sample of the present study refers to the year 2002 and consists of 36 companies, 10 of which are trading companies and all the others are producing fast moving consumer goods. The sample consists of few firms since there are advertising data only for big and especially international firms. In addition, it was decided that firms with advertisement expenditures less than 100.000 euro would be neglected or ignored.

Despite the small size of the sample, the obtained results can be considered as quite representative, because the studied firms can be termed as leading firms in the industry with a sufficiently great effort for the Greek market.

In order to investigate the impact of market share and /or advertisement on the profitability, equation (4) was estimated using cross-section analysis.

\section{EMPIRICAL RESULTS}

The results of the cross-section analysis are given by the following equation:

lpgi $=11.7971+0.174320 \log \mathrm{ad}_{\mathrm{i}} / \mathrm{s}+0.488342 \log \mathrm{m}_{\mathrm{i}}$
(31.5387)
(1.75287)
(6.38861)

In order to test the accuracy of the above equation some diagnostics, such as Durbin Watson, $\mathrm{R}^{2}$, Chow test and Jarcque - Bera test, were investigated. 
Durbin Watson coefficient ( $\mathrm{DW}=2.63$ ) is greater than the upper critical value provided by the table of the $\mathrm{D}$ $\mathrm{W}$ statistic and close to 2, meaning that there is no evidence of autocorrelation between the residuals. Under these circumstances, the cross-section analysis seems to be appropriate for our model.

It is known that the association between the explanatory variables (multicolinearity problem) is measured by the correlation coefficient. In our study, the correlation coefficient between advertising to sales ratio and market share was found 0.051 . The low correlation indicates that multicolinearity is not a problem in our study.

The coefficient of multiple determination $\mathrm{R}^{2}$ computed as 0.58 , means that $58 \%$ of the variation in profitability can be explained by the variation in the advertising to sales ratio and the variation in market share. The value of $\mathrm{R}^{2}$ is very satisfactory for the cross-section analysis. However, when dealing with multiple regression models, the adjusted $\mathrm{R}^{2}$ should be computed to reflect both the number of explanatory variables in the model and the sample size. Since $R_{a d j}^{2}=0.55,55 \%$ of the variation in profitability can be explained by the above model adjusted for number of predictors and sample size.

The reported results indicate a strong positive relationship between market - share and gross profit. Market share proved a very good explanation variable in its second power. This relationship indicates that firms use market share to create entry barriers irrespective of being in a particular industry. Market - share are very important entry barriers and as such an element of oligopolistic rivalry.

The relationship between advertising to sales ratio and the gross profit proved positive but not statistically significant. This means that advertising to sales ratio is of persuasive character leading to a change in the firm's demand curve. In this way advertising to sales ratio is an entry barrier and a mean of oligoposistic rivalry.

The value of the Chow -test (F-test) is 1.17 , which is less than the critical value provided by the tables, indicates stability of coefficient.

The value of the Jarcque - Bera test is 1.65 , which is less than the critical value provided by the tables indicating a normal distribution. We have also test autocorrelation with Breusch - Godfrey test and Ljung - Box statistic. Their values indicate absence of autocorrelation.

The profitability of the firms is explained by the two explanatory variables. This seems a very reasonable result because profitability is very much affected by market - share and advertisement and because the two variables lead to barriers to entry, which increase the profitability. We also observe that the coefficient of the market - share is greater than the coefficient of the advertising to sales ratio and both of them are statistically significant at the 5\% level.

To further determine the contribution of explanatory variables the partial F-test statistic was used.

In order to determine the contribution of variable $\mathrm{j}$, assuming that all other variables are already included, the following equation can be used.

$$
\begin{aligned}
& \operatorname{SSR}\left(X_{j} \mid \text { all variables except } j\right)= \\
& \operatorname{SSR}(\text { all variables including } j)-\operatorname{SSR}(\text { all variables except } j)
\end{aligned}
$$

The term $\operatorname{SSR}\left(X_{j}\right)$ represents the regression sum of squares for a model that includes only the variable $X_{j}$. The null and the alternative hypothesis should be investigated to test for the contribution of $X_{j}$ to the model.

$\mathbf{H}_{\mathbf{0}}$ : Variable $X_{j}$ does not significantly improve the model after all the other variables have been included.

$\mathbf{H}_{1}$ : Variable $X_{j}$ significantly improves the model after all the other variables have been included. 
The partial F-test statistic is defined by:

$$
F=\frac{\operatorname{SSR}\left(X_{j} \mid \text { all variables except } j\right)}{\text { Error Mean Square }(M S E)}
$$

while the coefficients of partial determination can now be written as:

$$
\begin{aligned}
& R_{Y j,(\text { all variables except } j)}^{2}= \\
& \quad=\frac{\operatorname{SSR}\left(X_{j} \mid \text { all var iables except } j\right)}{S S T-S S R(\text { all var iables including } j)+S S R\left(X_{j} \mid \text { all var iables except } j\right)}
\end{aligned}
$$

To apply the partial F-test criterion in our study, one need to evaluate the contribution of advertising to sales ration after market share has been included in the model and conversely one must also evaluate the contribution of market share after advertising to sales ratio has been included in the model. The obtained results are illustrated in Table I.

Table I

Partial F-Test Criterion

\begin{tabular}{|c|c|c|c|c|c|}
\hline & SSR & MSE & SST & F & $R_{Y}^{2}$ \\
\hline $\boldsymbol{X}_{\boldsymbol{I}}$ & 0.422 & & & & \\
\hline $\boldsymbol{X}_{\mathbf{2}}$ & 4.079 & & & & \\
\hline $\boldsymbol{X}_{\boldsymbol{I}}$ and $\boldsymbol{X}_{\mathbf{2}}$ & 4.377 & 2.188 & 7.574 & & 0.085 \\
\hline $\boldsymbol{X}_{\boldsymbol{I}} \boldsymbol{X}_{\mathbf{2}}$ & 0.298 & & & 3.073 & 0.553 \\
\hline $\boldsymbol{X}_{\mathbf{2}} \boldsymbol{X}_{\boldsymbol{I}}$ & 3.955 & & & 40.82 & \\
\hline
\end{tabular}

$X_{1}$ : Advertising to sales ratio

$X_{2}$ : Market share

SST: Total sum of squares for Y (profitability)

Table I depicts that the addition of market share significantly improves the model that already contains advertising to sales ratio. This happens because the partial F-test statistic $(F=40.82)$ is greater than the critical $\mathrm{F}$ value (from tables) and hence the decision is to reject $\mathrm{H}_{0}$. The coefficient of partial determination of profitability with market share while holding advertising to sales ratio constant $R_{Y 1,2}^{2}=0.553$, means that for constant advertising to sales ratio, $55.3 \%$ of the variation in profitability can be explained by the variation in the market share.

In the same way, the partial F-test statistic for the advertising to sales ratio $(F=3.073)$ is slightly smaller than the critical $\mathrm{F}$ value (from tables) and hence the null hypothesis can not be rejected. It is then understood that the addition of advertising to sales ratio marginally improve the model that already contains market share. Since $R_{Y 2,1}^{2}=0.085,8.5 \%$ of the variation in profitability can be explained by the variation in the advertising to sales ratio.

Thus, by testing for the contribution of each explanatory variable after the other has been included in the model, it is deduced that only market share significantly affects profitability. Hence, advertising to sales ratio can be ignored from the model. These results also verify the t-test results for the advertising to sales ratio mentioned above.

\section{CONCLUSIONS}

In this work the impact of market share and advertising of sales ratio on companies' profitability was investigated. Cross section analysis with firm level data were used to examine the relationship between gross profit, 
market share, as an appropriate strategy and plasmatic differentiation (measured by adverting to sales ratio) of 36 companies which produce fast moving consumer goods for the year 2002.

The obtained results show that market share greatly influences profitability. This fact was expected since market share establishes strong entry barriers and creates oligopolistic markets, which was proved in previous empirical and theoretical studies. In contrast to our expectation, advertising to sales ratio seems to affect profitability less than market share. The relationship between advertising to sales ratio and profitability can be explained from the fact that advertisement puts barriers of entry especially for companies of oligopolistic competition, or for companies, which produce fast moving consumer goods products, or for those, which distribute and sell such types of products.

To further determine the contribution of market share and advertising to sales ratio the partial $\mathrm{F}$ - test was used. It was deduced that advertising to sales ratio was less significant than market share. These results also verify the $\mathrm{t}$ - test results for the advertising to sales ratio.

\section{REFERENCES}

1. Beath, J., Katsoulacos, Y., and Ulph, D. (1987), Sequential Product Innovation and Industry Evolution. Economic Journal (Supplement), Vol. 97, pp 32 - 43.

2. Beath, J., Katsoulacos, Y., and Ulph, D. (1992), Sequential Product Innovation with Endogenous Market Structure, in A. Gee and G. Norman, (eds), Market Structure and Market Strategy, London: Wheatseaf, pp. $329-350$.

3. Beath, J. and Ulph, D. (1990), The Trade - Off between Static and Dynamic Efficiency in a Non-Tournament Model of Innovation, University of Bristol, Discussion Paper, 90/286.

4. Boulding, W. and Staelin, R. (1990), A Look on the Cost Side: Market Share and Industry Structure, unpublished manuscript.

5. $\quad$ Buzzell, R. D. and Gale, B.T. (1987), The PIMS Principles, Free Press, New York, N.Y.

6. Cave, R. E. and Williamson, P. J. (1985), What is Product Differentiation, really?, Journal of Industrial Economics, Vol. 34, No 2, pp. $113-132$.

7. Comanor, W. S. (1967), Market Structure, Product Differentiation and Industrial Research, Quarterly Journal of Economics, Vol. 81, No 4, pp. $639-657$.

8. Cool, K. D. I. and Jemison, D. (1989), Business Strategy, Market Structure and Risk-Return Relationship: a Structural Approach, Strategic Management Journal, Vol. 10, November - December, pp.507 - 522.

9. Frearing, J. M. (1994), The Industry - Specific Basis of the Market Share Profitability Relationship, Journal of Consumer Marketing, Vol. 11, No.1, pp.1-10.

10. Gale, B. T. (1972), Market Share and the Rate of Return, Review of Economics and Statistics, Vol. 54, pp. $412-423$.

11. Greuner, Mathias R., Kamerschen, David R., and Klein, Peter G. (2000), The competitive Effects of Advertising in the US Automobile Industry, 1970 - 1994, International Journal of Economics and Business, Vol. 7, pp 245-61.

12. Jacobson, R. (1988a), Distinguishing among Competing Theories of the Market Share Effect, Journal of Marketing, October, Vol. 52, pp. $68-80$.

13. Jacobson, R. and Aaket, D. A. (1985), Is Market Share all that it's Cracked up to be?, Journal of Marketing, Fall, Vol. 49, pp.11 - 22.

14. Kaldor, N. (1950), The Economic aspects of Advertising, Review of Economic Studies, Vol. 18, pp. 1-27.

15. Kessides, I. N. (1986), Advertising, Sunk Cost and Barriers to Entry, Review of Economics and Statistics, LXVIII.

16. Mata J. (1993), Firm entry and firm growth', Review of Industrial Organization, No. 8, pp.567-578.

17. Martin, S. (1994), Industrial Economics: Economic Analysis and Public Policy, Prentice - Hall International.

18. Milgrons, P. and Roberts, J. (1986), Price and Advertising as Signals of Product Quality, Journal of Political Economy, Vol. 94, No. 4, pp. $796-821$.

19. Mueller, W. F. And Rogers, R. T. (1980), The Role of Advertising in Changing Concentration of Manufacturing Industries', Review of Economics and Statistics, Vol. 52, No. 1, pp. 89 - 96.

20. Nelson, P. (1974), Advertising as Information, Journal of Political Economy, Vol. 82, No. 4, pp. 729 - 754. 
21. Pitelis, C. N. (1991), The Effects of Advertising and Investment on Aggregate Profits, Scottish Journal of Political Economy, Vol. 38, No. 1, February.

22. Reekie, D. W. (1981), Profitability and intangible assets: Another Look at Advertising and Entry Barriers, Applied Economics, No 13, pp. 99-107.

23. Rumelt, R.P. and Wensley, R. (1981,) In Search of the Market Share Effect, Proceedings of the Academy of Management, pp.2-6.

24. Schmalensee, R. (1976), Advertising and Profitability: Further Implications of the Null Hypothesis, The Journal of Industrial Economics, No. XXV, No 1.

25. Schwalbach, J. (1981), Profitability and Market Share: A Reflection on the Functional Relationship, Strategic Management Journal, No. 1. No. 12, pp. 299 - 306.

26. Shepherd, W. G. (1972), The Elements of Market Structure, Review of Economics and Statistics, February, Vol. 54, pp. $25-37$.

27. Szymanski, D. M., Bharadwaj, S. G. And Varadarajan, P. R. (1993), An Analysis of the Market Share Profitability Relationship, Journal of Marketing, July, Vol. 57, No.3, pp.1 - 18.

28. Venkatraman, N. and Prescott, J. E. (1990), The Market Share Profitability Relationship: Testing Temporal Stability across Business Cycles, Journal of Management, Vol. 16, No. 4, pp. 783 - 805.

29. Woo, C. Y. (1982), The surprising Case of Low Market Share, Harvard Business Review, Vo, 60, No. 6, November/December, pp. $106-13$.

\section{NOTES}


NOTES 